Technical Note

\title{
Colchicine: Isolation, LC-MS QTof Screening, and Anticancer Activity Study of Gloriosa superba Seeds
}

\author{
Acharya Balkrishna, Subrata K. Das, Subarna Pokhrel, Alpana Joshi, Laxmi, Sudeep Verma, \\ Vinai K. Sharma, Vinamra Sharma, Niti Sharma and C. S. Joshi *D
}

Drug Discovery \& Development Division, Patanjali Research Foundation (Trust), Near Patanjali Yogapeeth-I, Haridwar, Pin- 249405 Uttarakhand, India

* Correspondence: drcsjoshi19@yahoo.com; Tel.: +91-790-638-3037

Academic Editor: Ericsson Coy-Barrera

Received: 28 May 2019; Accepted: 22 July 2019; Published: 30 July 2019

check for updates

\begin{abstract}
Colchicine was extracted from Gloriosa superba seeds using the Super Critical Fluid $\left(\mathrm{CO}_{2}\right)$ Extraction (SCFE) technology. The seeds were purified upto $99.82 \%$ using column chromatography. Colchicine affinity was further investigated for anticancer activity in six human cancer cell lines, i.e., A549, MCF-7, MDA-MB231, PANC-1, HCT116, and SiHa. Purified colchicine showed the least cell cytotoxicity and antiproliferation and caused no G2/M arrest at clinically acceptable concentrations. Mitotic arrest was observed in only A549 and MDA-MB231 cell lines at $60 \mathrm{nM}$ concentration. Our finding indicated the possible use of colchicine at a clinically acceptable dose and provided insight into the science behind microtubule destabilization. However, more studies need to be conducted beforethese findings could be established.
\end{abstract}

Keywords: Gloriosa superba; super critical fluid $\left(\mathrm{CO}_{2}\right)$ extraction (SCFE); colchicine; cytotoxicity; cell cycle

\section{Introduction}

Traditionally, Gloriosa is used in the treatment of various clinical conditions like inflammation, edema, rheumatism, skin infections, arthritis, alopecia, and many others [1-3].Colchicine is an alkaloid present in the seeds of Colchicum autumnale L. and Colchicum luteum L., as well as in tubers of Gloriosa superba L. (family Liliaceae) [4]. Gloriosa grows throughout the tropical region in India and is a well-known source of colchicine. Its use is associated with a decreased risk of incidence in all types of cancers $[5,6]$. On the basis of dry mass, Colchicum and Gloriosa contains $0.62 \%$ to $0.9 \%$ of colchicine $[7,8]$. The higher content of colchicine in Gloriosa than in Colchicum makes it a commercially viable source of this medicine $[9,10]$. Several techniques have been developed to extract colchicine, and among these 'soxhlet and solid-liquid extraction' are the most commonly used [11,12]. Extraction of colchicine from C. autumnale using methanol [6], and from Gloriosa seeds by methanol [13] and ethanol [14] has also been reported.

In recent years, the use of Super Critical Fluid $\left(\mathrm{CO}_{2}\right)$ Extraction (SCFE) for extraction of phytochemicals has been fast increasing. SCFE is superior when compared to the traditional solvent extraction because the final extract is inexpensive and free from residual solvents. Additionally, SCFE extraction with $\mathrm{CO}_{2}$ is considered to be an environment-friendly technology [14-18]. The SCFE is also used along with a co-solvent, which enhances the extraction efficiency $[15,19-25]$. Colchicine was studied for its tubulin inhibitory activity and was found to bind at a location where it prevents curved tubulin [26]. Colchicine is used as a remedy for treating gout [27], and as an antidote for snake bite [28] 
and Familial Mediterranean Fever [29,30]. Due to its significant role in pharmaceuticals, its extraction and production with the lowest impurity content is immensely important.

Colchicine is a well-known potent microtubule targeting agent. It disrupts microtubule functions by binding to various sites on $\beta$-tubulin causing mitotic arrest (hyperploidy) [31-34]. The binding of colchicine to microtubules dissociates them in to tubulin dimers, thereby interfering with the polymerization of tubulin and interrupting microtubule dynamics $[35,36]$. Colchicine possesses anti-cancerous activity and the mechanism involves inhibition of G1 to M phase progression (G2/M phase arrest) of cell cycle, by disrupting the formation of the mitotic spindle required for mitosis $[32,37,38]$. Cell cycle arrest regulates cell growth by arresting cell proliferation and induces cell death $[39,40]$. The rate of mitosis is increased in cancer cells and microtubules formed during mitosis are considered as an ideal target for anticancer drugs [41]. The therapeutic use of colchicine as an anticancer drug is limited due to its toxicity to non-cancerous cell, but oral colchicine is a safe medicine when the dose is used in a controlled way and contraindications are limited [30,41,42].

Colchicine was approved by the Food and Drug Administration (FDA, USA) as a drug for gout, in 2009, and as a single ingredient in the liquid form, in 2019.This has encouraged profound interests in colchicine research and applications. This was the first time colchicine was extracted from Gloriosa seeds using SCFE technology and was standardized for purity, with respect to the reference standards, using High Performance Liquid Chromatography (HPLC). LC-MS quadrupole time-of-flight (QTof) was used for the determination of the seed's chemical composition $[43,44]$. Our present study indicated that purified colchicinein low doses has the least cytotoxic effect on human cell lines. Anticancer effect of colchicine was further investigated in six human cancer cell lines.

\section{Materials and Methods}

\subsection{Plant Material and Chemicals}

The Gloriosa superba seeds were procured from Salem, Tamil Nadu (India) in February 2016. Liquid $\mathrm{CO}_{2}$ of high purity (CAS No. 124-38-9) was procured from the local industrial gas supplier. The solvents used were of LR grade (Qualigens Fine Chemicals, Mumbai, India). Untreated activated charcoal (CAS No. 7440-44-0) (particle size $<75$ microns) was obtained from Sigma (St. Louis, MO, USA). Alumina neutral activity I-II (Neutral Aluminum oxide active) (CAS No. 1344-28-1) was obtained from Merck India, Mumbai, India. All analytical solvents used were of HPLC grade and were procured from Merck India, Mumbai, India. LC-MS grade solvents were procured from Honeywell, Germany. Colchicine reference standard was procured from Natural Remedies, Bangalore, India.

\subsection{Super Critical Fluid Extractor}

Super Critical Fluid $\left(\mathrm{CO}_{2}\right)$ Extractor (Waters Co-Botanical Extraction System 5000) was designed with a $3 \mathrm{Kg}$ loading capacity of the raw material. $\mathrm{SCF}\left(\mathrm{CO}_{2}\right)$ extractor was equipped with two separators (collection vessels), using the phenomena of high and low-pressure zones, in the different separators (Figure 1). 


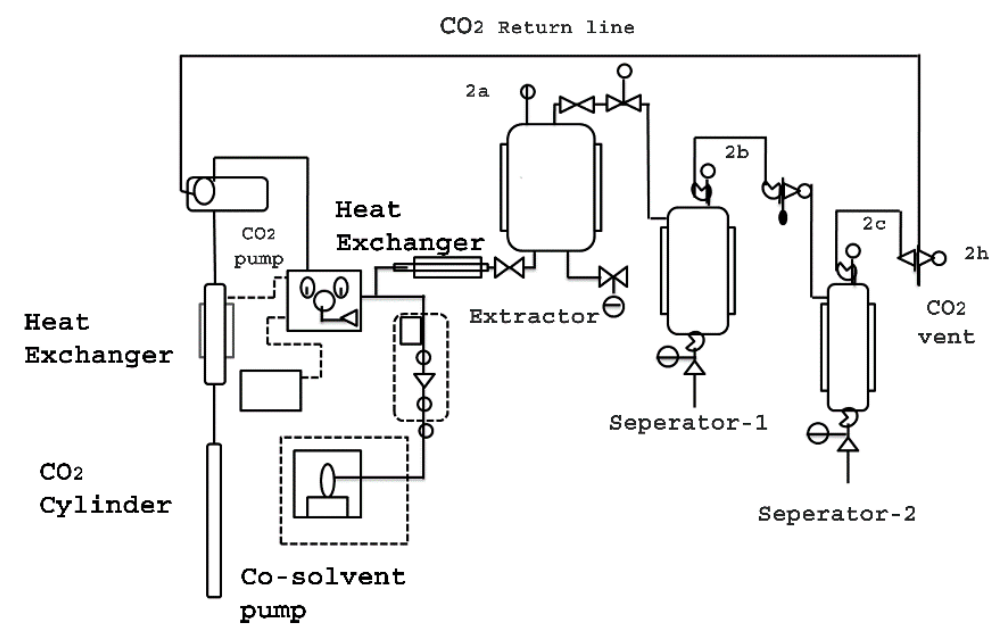

Figure 1. Schematic diagram showing Supercritical Fluid Extractor (2a, 2b, 2c, and $2 \mathrm{~h}$ are the pressure valves).

\subsection{Super Critical Fluid $\left(\mathrm{CO}_{2}\right)$ Extraction}

Gloriosa superba seeds $\left(3 \mathrm{Kg}\right.$ ) were extracted using Super Critical $\mathrm{CO}_{2}$ extractor, at a temperature of $60{ }^{\circ} \mathrm{C}$ and varying pressure of $200-450$ bars. The separators were kept at different pressures and temperatures, i.e., 350 bar at $50{ }^{\circ} \mathrm{C}$ and 100 bar at $15^{\circ} \mathrm{C}$, respectively. Therefore, the extract was collected in separator1, while wax material, fatty acids and other volatile materials were collected in separator2. The extraction was carried out with liquid $\mathrm{CO}_{2}$ with $3 \%$ water as co-solvent. Water was used as a co-solvent for extraction to enhance the extraction efficiency and water was removed from the extract by applying low pressure, while it was moved to the separator 2. After placing the basket containing seeds powder inside the extractor, heating/cooling systems were turned $\mathrm{ON}$. The liquid $\mathrm{CO}_{2}$ flow rate was kept at a constant $100 \mathrm{~g}$ per minute while $3 \mathrm{~g}$ of co-solvent water $\left(3 \%\right.$ of liquid $\left.\mathrm{CO}_{2}\right)$ was used as the extraction media. Once the extraction cylinder temperature reached $60{ }^{\circ} \mathrm{C}$, the pressure valves $2 \mathrm{a}, 2 \mathrm{~b}, 2 \mathrm{c}$, and $2 \mathrm{~h}$ were opened. Each extraction was carried out for $3 \mathrm{~h}$. The yield at different extraction pressure conditions was plotted and analyzed (Table 1).

Table 1. Gloriosa superba extraction and yield correlation.

\begin{tabular}{ccccccc}
\hline Exp. No. & $\begin{array}{c}\text { Gloriosa Seeds } \\
\text { Loaded (Kg) }\end{array}$ & $\begin{array}{c}\text { Pressure of } \\
\text { Extractor }\end{array}$ & $\begin{array}{c}\text { Temp } \\
\left({ }^{\circ} \mathbf{C}\right)\end{array}$ & $\begin{array}{c}\text { Flow Rate of Liquid } \\
\mathbf{C O}_{\mathbf{2}}(\mathbf{g} / \mathbf{m i n}) \mathbf{( 3 \% \text { Water }} \\
\text { as co Solvent) }\end{array}$ & $\begin{array}{c}\text { Yield (G) } \\
\text { Colchicine of } \\
\text { (HPLC) (\%) }\end{array}$ \\
\hline 1 & 3.0 & 200 & 60 & 100 & 1.2 & Nil, waxy \\
2 & 3.0 & 250 & 60 & 100 & 5.0 & 3.0 \\
3 & 3.0 & 300 & 60 & 100 & 10.3 & 6.92 \\
4 & 3.0 & 350 & 60 & 100 & 56.2 & 20.3 \\
5 & 3.0 & 400 & 60 & 100 & 72.8 & 27.0 \\
6 & 3.0 & 450 & 60 & 100 & 80.1 & 16.15 \\
\hline
\end{tabular}

\subsection{Isolation of Colchicine}

The SCF extract from separator 1 was collected and cooled to room temperature. Concentrated extract was dissolved in de-mineralized water $(5 \mathrm{~L})$ and filtered using a hiflo-supercell bed. The aqueous layer was partitioned using ethyl acetate $(10 \mathrm{~L} \times 2$ times). The combined ethyl acetate layer was washed using de-mineralized water $(1 \mathrm{~L})$, to remove the phenolic impurities. The ethyl acetate layer was then concentrated and dried at $50{ }^{\circ} \mathrm{C}$, under vacuum. The dried mass $(72.8 \mathrm{~g})$ was dissolved in ethanol $(200 \mathrm{~mL})$, passed through an activated charcoal $(50 \mathrm{~g})$ columnand was eluted using ethanol $(2 \mathrm{~L})$. The ethanol elute was concentrated to dryness under vacuum, at $50{ }^{\circ} \mathrm{C}$. Finally, the dried mass $(19.1 \mathrm{~g})$, which was found to be $96.7 \%$ pure, was dissolved in $200 \mathrm{~mL}$ ethyl acetate and was passed through a neutral alumina column ( $200 \mathrm{~g}$, activity I-II). The column was eluted using ethyl acetate; the combined 
elute was concentrated to $100 \mathrm{~mL}$, under vacuum, at $40^{\circ} \mathrm{C}$, and was kept for crystallization for $1 \mathrm{~h}$, at room temperature. The crystalline mass was filtered using a Buchner funnel and was dried at $30{ }^{\circ} \mathrm{C}$, under vacuum (1 torr), for $24 \mathrm{~h}$. This yielded $17.83 \mathrm{~g}(85.2 \% \mathrm{w} / \mathrm{w})$ of light yellow crystalline mass containing colchicine $99.82 \%(w / w)$ assay. The analysis was performed using high performance liquid chromatography.

\subsection{Preparation of Solutions for HPLC Analysis}

A standard stock solution of $473.76 \mu \mathrm{g} / \mathrm{mL}$ was prepared by dissolving $4.8 \mathrm{mg}$ of Colchicine (purity 98.7\%) in HPLC grade methanol, in a $10 \mathrm{~mL}$ volumetric flask and completely filled.

The sample solution was prepared using $2 \mathrm{~g}$ of homogenized Gloriosa seed powder in a $250 \mathrm{~mL}$ round bottom flask-50 mL of HPLC grade methanol was added to it and refluxed for $1 \mathrm{~h}$ in a water bath and cooled; the solution was then transferred into a $100 \mathrm{~mL}$ volumetric flask and HPLC grade methanol was added to it until the volume increased to $100 \mathrm{~mL}$. For the samples of the SCFE extracts, $0.5 \mathrm{~g}$ of the extract was dissolved in $50 \mathrm{~mL}$ of HPLC grade methanol, while $5.01 \mathrm{mg}$ of purified colchicine was dissolved in $10 \mathrm{~mL}$ of HPLC grade methanol.

\subsection{HPLC Chromatographic Conditions}

Analysis was performed on Waters HPLC equipped with an on-line degasser, AP 1525 Binary HPLC pump, 2707 Auto Sampler, 2998 Photodiode Array Detector, and Empower-3 software. The XBridge C18 column $(250 \times 4.6 \mathrm{~mm}, 5 \mu \mathrm{m})$ was maintained at $40{ }^{\circ} \mathrm{C}$ throughout the analysis and detection was carried out at $245 \mathrm{~nm}$. The flow rate was maintained at $1 \mathrm{~mL} / \mathrm{min}$ using isocratic elution of mobile phase Water:Acetonitrile (75:25). A total of $10 \mu \mathrm{L}$ of the sample solutions was injected for the analysis and the chromatograph was recorded for $20 \mathrm{~min}$ (Figure 2).

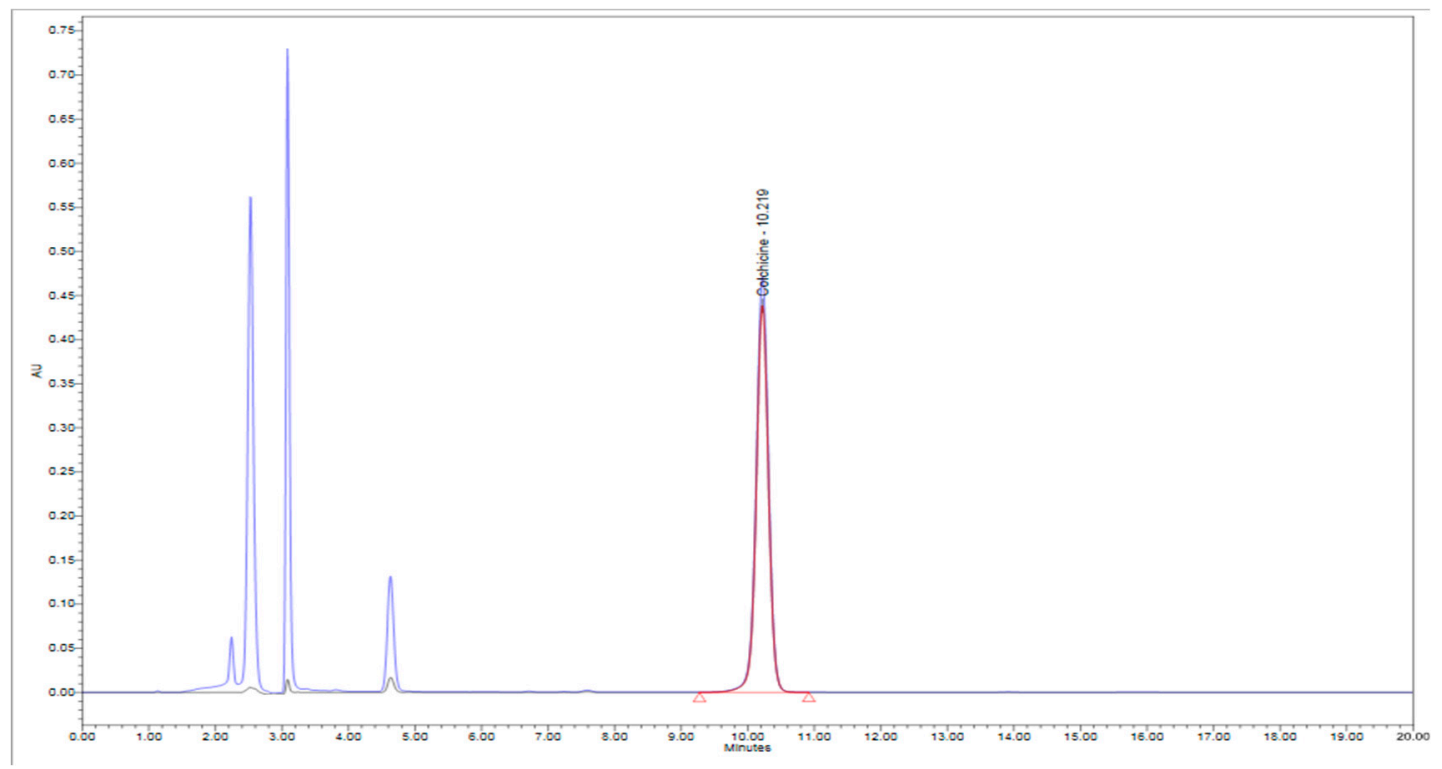

Figure 2. HPLC Chromatograph of the Colchicine standard and the Gloriosa seed extract.

\subsection{Preparation of Sample Solution for LC-MS QTof Screening}

Liquid chromatography-mass spectrophotometry/quadrupole time-of-flight screening was done for studying the chemical composition of the Gloriosa seeds. A total of $10 \mathrm{~mL}$ of methanol:water mixture (80:20) was added to $201.0 \mathrm{mg}$ of powdered Gloriosa superba seeds and sonicated for $15 \mathrm{~min}$. This solution was centrifuged for $5 \mathrm{~min}$ at $5000 \mathrm{rpm}$ and filtered through a $0.22 \mu \mathrm{m}$ nylon filter. 


\subsection{LC-MS QTof Conditions}

The LC-MS QTof instrument was equipped with an ESI ion source operating in a positive and negative ion mode. A mass range of 50-1000 Da was set with a $0.2 \mathrm{~s}$ scan time. The main working parameters for mass spectrometry were set as follows, ionization type-ESI, mode- $\mathrm{MS}^{\mathrm{E}}$, acquisition time $-30 \mathrm{~min}$, mass range $(\mathrm{m} / \mathrm{z})-50-1000 \mathrm{~m} / \mathrm{z}$, low collision energy $-6 \mathrm{eV}$, high collision energy $-20-40 \mathrm{eV}$ (ramp), cone voltage $-40 \mathrm{~V}$, capillary voltage $-1 \mathrm{kV}$ (for positive mode) (Figure 3A), capillary voltage $-2 \mathrm{kV}$ (for negative mode) (Figure 3B), source temperature-120 ${ }^{\circ} \mathrm{C}$, desolvation temperature $-500{ }^{\circ} \mathrm{C}$, cone gas flow- $50 \mathrm{~L} / \mathrm{h}$, desolvation gas flow- $800 \mathrm{~L} / \mathrm{h}$. Mass was corrected during acquisition, using an external reference (Lock-Spray) consisting of $0.2 \mathrm{ng} / \mathrm{mL}$ solution of leucine enkephalin infused at a flow rate of $10 \mu \mathrm{L} / \mathrm{min}$ via a lock-spray interface, generating a reference ion for the positive ion mode $[(\mathrm{M}+\mathrm{H})+m / z 556.2766]$ and for the negative ion mode $[(\mathrm{M}+\mathrm{H})+m / z$ 554.2620] to ensure mass accuracy during the MS analysis. The Lock-Spray scan time was set at $0.25 \mathrm{~s}$ with aninterval of $30 \mathrm{~s}$.Analysis was performed on a Waters Xevo G2-XS QTof equipped with Acquity UPLC-I Class and Unifi software. Separation was carried out using Acquity UPLC HSS-T3 column $(100 \times 2.1 \mathrm{~mm}, 1.7 \mu \mathrm{m})$. The column was maintained at $50{ }^{\circ} \mathrm{C}$ throughout the analysis, and sample temperature was kept at $10^{\circ} \mathrm{C}$. The elution was carried out at a flow rate of $0.4 \mathrm{~mL} / \mathrm{min}$ using gradient elution $0.1 \%$ formic acid in water (mobile phase $\mathrm{A}$ ) and $0.1 \%$ formic acid in acetonitrile (mobile phase B). Solvent gradient program was $95 \%-85 \%$ of the mobile phase A during $0-4 \mathrm{~min}, 85 \%-80 \%$ A during 4-15 min, 80\%-75\% A during 15-20 min, 75\% A during 20-28 min, 75\%-60\% A during $28-31 \mathrm{~min}$, 60\%-10\% A during 31-32 min, 10\% A during 32-34 min, 10\%-95\% A during 34-35 min, followed by 95\% A during 35-37 min. A total of $1 \mu \mathrm{l}$ of the test solution was injected for the screening and the chromatograph was recorded for $30 \mathrm{~min}$.

\subsection{Cell Lines and Culture Condition}

The six human cancer cell lines, lung cancer (A549), breast cancer (MCF-7 and MDA-MB231), pancreatic carcinoma (PANC-1), colon carcinoma (HCT116), and cervical cancer (SiHa) were obtained from National Centre for Cell Science (NCCS) Pune, India. Cell lines were cultured in a DMEM medium supplemented with 10\%FBS and $1 \mathrm{X}$ antibiotic. The cultured cells were seeded in 24-well plate at a density of $0.05 \times 10^{6}$ and grown overnight at $37^{\circ} \mathrm{C}$ in a humidified atmosphere of $5 \% \mathrm{CO}_{2}$.

\subsection{Cell Cytotoxicity Assay}

Cell lines were seeded in 96-well plates $\left(1 \times 10^{4}\right.$ cells/mL). After $24 \mathrm{~h}$ incubation, the cells were treated with different concentrations of colchicine and Gloriosa extract (concentration was calculated on the colchicine content basis) 0-2560 $\mathrm{nM}$ for $48 \mathrm{~h}$. Cells were washed with PBS (twice), fixed with $10 \%$ formalin for $30 \mathrm{~min}$ and washed with $\mathrm{H}_{2} \mathrm{O}$. The cells were then stained with $0.5 \%(w / v)$ crystal violet $(25 \%(v / v)$ methanol) for $25 \mathrm{~min}$. After washing with water until no color was eluted, the cells were dried overnight. Crystal violet [45] was then eluted with $10 \%$ acetic acid and the absorbance of the solution was measured using a multi-mode plate reader (Perkin Elmer, EnVision) at a wavelength of $600 \mathrm{~nm}$.

\subsection{Cell Migration Assay}

Cells were seeded at a density of $0.05 \times 10^{6} \mathrm{cells} / \mathrm{mL}$ on a 24 -well plate. The confluent cell monolayer was scratched with a pipette tip, the floating cells were removed and treated with a varying dose of colchicine $(0-60 \mathrm{nM})$ and then imaged at $0,24,48$, and $72 \mathrm{~h}$ post-scratch. Three independent areas per treatment group were recorded, averaged for each time point, and plotted against time to calculate the rate of migration. The cell-free areas were measured using Carl Zeiss AxioVision SE64 Rel. 4.9.1 software (Germany). 


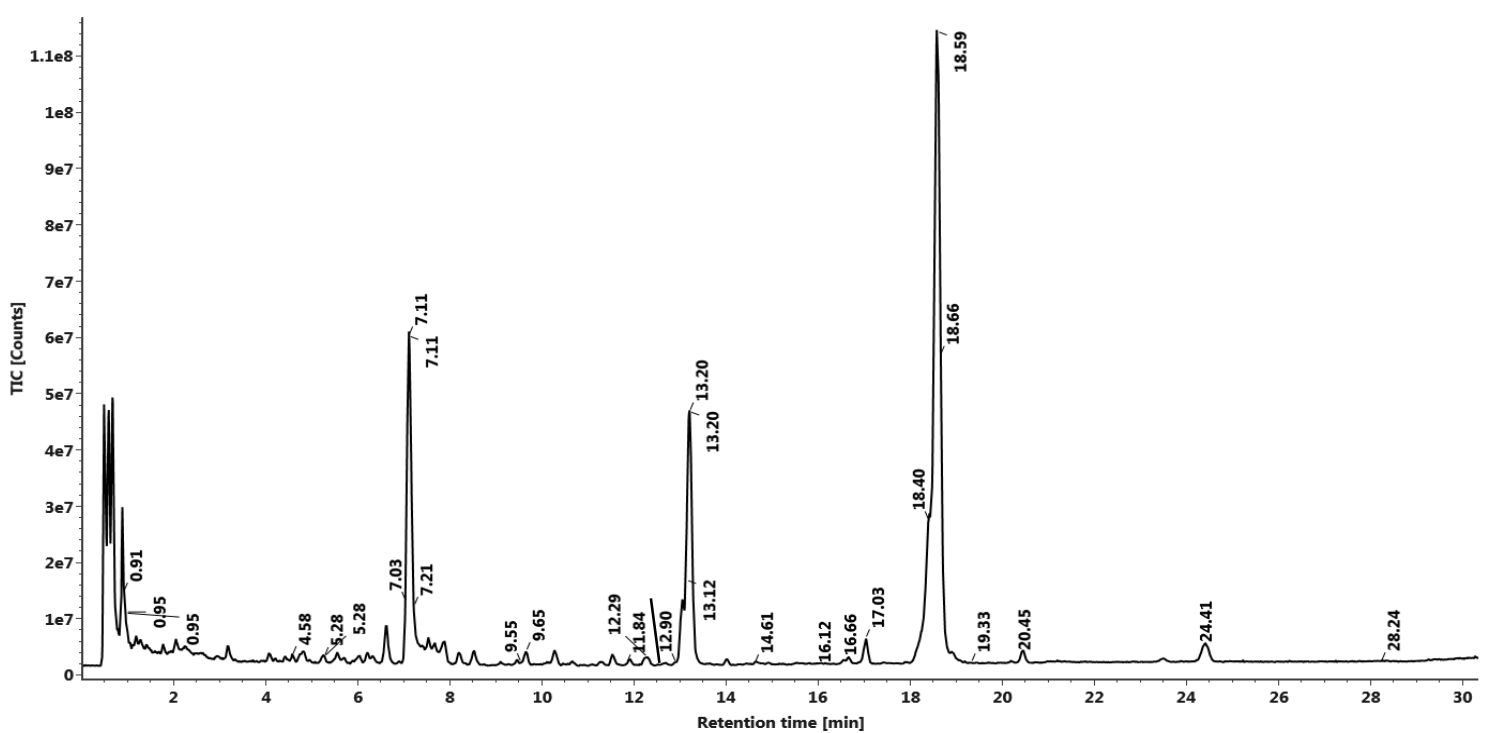

(A)

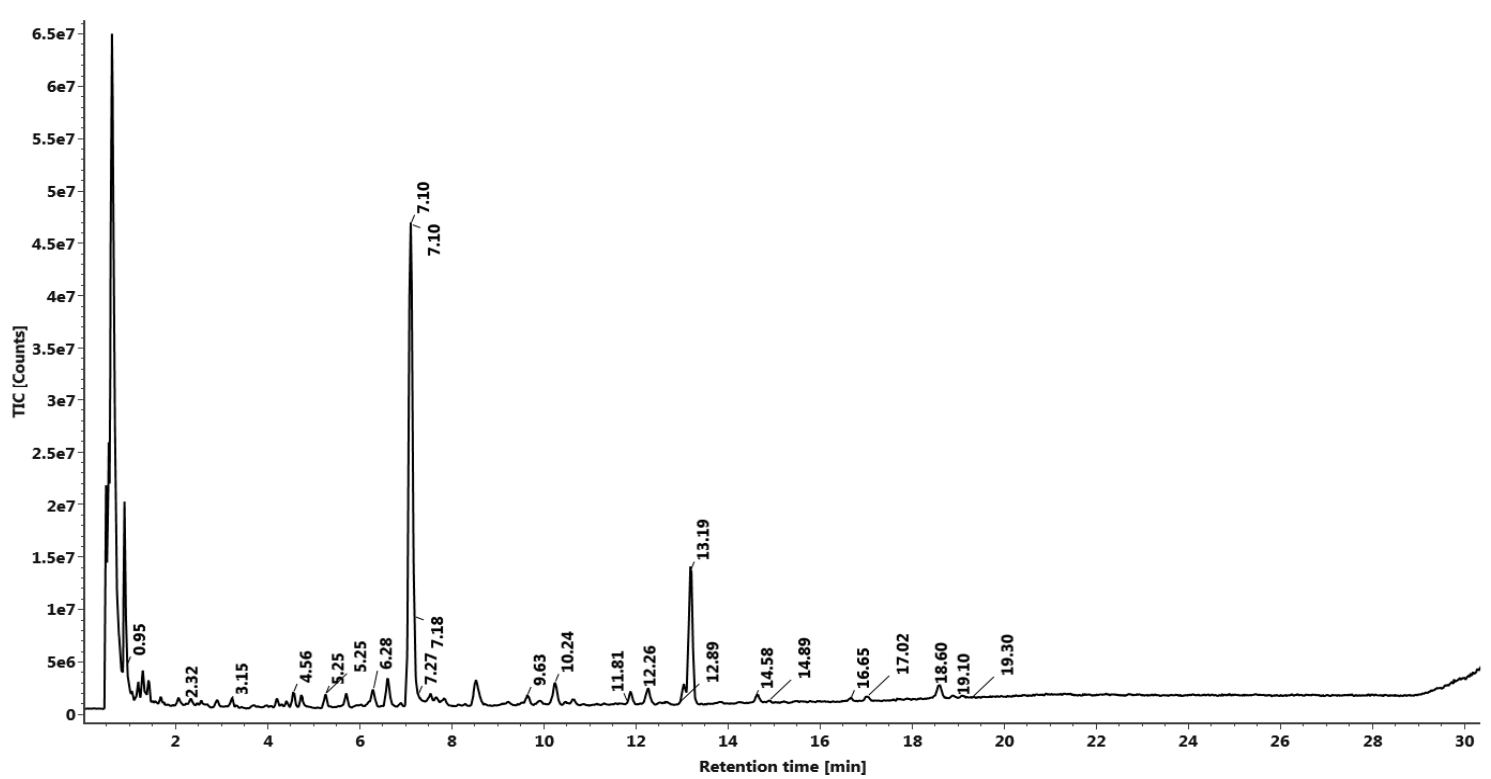

(B)

Figure 3. (A) UPLC-MS QTof Chromatograph of Gloriosa seed extract in the positive mode. (B) UPLC-MS QTof Chromatograph of Gloriosa seed extract in the negative mode.

\subsection{Cell Cycle Analysis by Flow Cytometry}

The cells were grown in 24-well plate for $24 \mathrm{~h}$ to study the effect of colchicine on cell cycle and were then treated with colchicine of different concentrations $(0,2.5,5,10,20,40$, and $60 \mathrm{nM})$. The cells were then incubated overnight at $37^{\circ} \mathrm{C}$ in a humidified atmosphere of $5 \% \mathrm{CO}_{2}$. The cells treated with colchicine were harvested and fixed in ice cold $70 \%$ ethanolin ice, for $1 \mathrm{~h}$. Then, the cells were incubated for $30 \mathrm{~min}$ at $37^{\circ} \mathrm{C}$ in a PBS solution containing $1 \mathrm{mg} / \mathrm{mL}$ RNaseA and $1 \mu \mathrm{g} / \mathrm{mL}$ propidium iodide (PI) solution. The cell cycle analysis was performed using Amnis Image Stream flow cytometer (Millipore, United States) and the data were analyzed based on 8000 events recorded using IDEAS image Stream Analysis Software. 


\subsection{Statistical Analysis}

Experimental values are expressed as mean \pm standard deviation of at least two experiments, in triplicates. The level of $p \leq 0.05$ was used as the criterion for statistical significance.

\section{Results}

\subsection{Super Critical Fluid Extraction}

Colchicine (a pharmacologically active constituent that has for centuries been used in acute gout arthritis [27]) was isolated on acommercial scale with high purity $99.82 \%,(w / w)$, quantified by HPLC.

This was the first time colchicine was extracted from Gloriosa seeds using Super Critical Fluid Extractor (SCFE) (Figure 1). The extractor was loaded with $3 \mathrm{Kg}$ of Gloriosa seeds powder containing $0.70 \%$ colchicine content for every batch. Liquid $\mathrm{CO}_{2}$ with $3 \%$ water was used as the co-solvent in the extraction medium, at varying pressure, i.e., 200, 250, 300, 350, 400, and $450 \mathrm{bar}$, at a temperature of $60{ }^{\circ} \mathrm{C}$, which was kept constant for two hours. The study showed that the extraction at a pressure of 400 bar gave an optimum yield of $93.6 \%(w / w)$, on the basis of the colchicine content, i.e., $27 \%$ colchicine content $(w / w)$ (Table 1$)$.

\subsection{Isolation and Quantification of Colchicine}

The isolation methodology involved column chromatographic separation in which the charcoal column separated most of the impurities, whereas the assay of $99.82 \%$ with a final yield of $85.2 \%$ was achieved when passed through the alumina columnand the final product was analyzed by HPLC (Figure 2). Structural elucidation was carried out by ${ }^{1} \mathrm{H}$ NMR and ${ }^{13} \mathrm{C}$ NMR spectroscopy, using JEOL $400 \mathrm{MHz}$ instrument (USA).

\subsection{LC-MS QTof Screening of Gloriosa Seeds}

Screening of the phytochemical composition of the Gloriosa seeds was analyzed using UPLC-MS QTof (Xevo G2-XS QTof, Waters with Acquity UPLC-I Class), where 32 compounds were identified in the positive mode of ionization (Figure $3 \mathrm{~A}$, Table 2 ) and 10 other constituents were identified in the negative mode of ionization (Figure 3B, Table 2), among the total 42 identified compounds.

Table 2. UPLC-MS QTof identified compounds of the Gloriosa superba seed in the positive and the negative mode.

\begin{tabular}{|c|c|c|c|c|c|c|}
\hline \multirow{2}{*}{ S. No. } & \multirow{2}{*}{ Component Name } & \multirow{2}{*}{ RT (min) } & \multicolumn{2}{|c|}{ Positive Mode } & \multicolumn{2}{|c|}{ Negative Mode } \\
\hline & & & Observed $m / z$ & Response & Observed $m / z$ & Response \\
\hline 1 & Chelidonic acid & 0.91 & 185.0079 & 3211 & - & - \\
\hline 2 & Adenosine & 0.95 & 268.1031 & 151304 & 266.0877 & 1956 \\
\hline 3 & o-Coumaric acid & 0.95 & 165.0537 & 23392 & - & - \\
\hline 3 & Vanillic acid & 2.32 & - & - & 167.0337 & 2640 \\
\hline 4 & $\begin{array}{l}\text { Vanillic acid } \\
\beta \text {-D-glucopyranosyl } \\
\text { ester }\end{array}$ & 3.15 & - & - & 329.0864 & 9708 \\
\hline 5 & $\begin{array}{l}\text { Catechin } \\
7-O-\beta \text {-D-glucopyranoside }\end{array}$ & 4.58 & 453.1383 & 14809 & 451.1238 & 131,920 \\
\hline 6 & (-)-Epicatechin & 5.28 & 291.0857 & 33690 & 289.0699 & 5584 \\
\hline 7 & Curculigoside B & 5.28 & 453.1383 & 23748 & 451.1241 & 109,583 \\
\hline 8 & Caffeic acid & 5.61 & - & - & 179.0335 & 4978 \\
\hline 9 & d-Isoboldine & 5.97 & 328.1536 & 100400 & - & - \\
\hline 10 & Gentiatibetine & 6.07 & 166.0851 & 6893 & - & - \\
\hline
\end{tabular}


Table 2. Cont.

\begin{tabular}{|c|c|c|c|c|c|c|}
\hline \multirow{2}{*}{ S. No. } & \multirow{2}{*}{ Component Name } & \multirow{2}{*}{ RT (min) } & \multicolumn{2}{|c|}{ Positive Mode } & \multicolumn{2}{|c|}{ Negative Mode } \\
\hline & & & Observed $m / z$ & Response & Observed $m / z$ & Response \\
\hline 11 & Procyanidin B7 & 6.28 & - & - & 577.1358 & 227,928 \\
\hline 12 & Daidzein & 7.03 & 255.0659 & 4567 & - & - \\
\hline 13 & Colchicoside & 7.11 & 548.2137 & 2177554 & 546.1986 & 213,123 \\
\hline 14 & 2-demethylcolchicine & 7.11 & 386.16 & 556495 & 384.1445 & $1,186,230$ \\
\hline 15 & Catechin & 7.21 & 291.0853 & 38106 & 289.0702 & 93,291 \\
\hline 16 & Isoastilbin & 7.27 & - & - & 449.1079 & 28,723 \\
\hline 17 & 6-Hydroxykaempferol & 9.55 & 303.0498 & 3793 & - & - \\
\hline 18 & $\begin{array}{l}\text { 1,2-didemethyl } \\
\text { colchicine }\end{array}$ & 9.65 & 372.1443 & 322523 & 370.1283 & 27,794 \\
\hline 19 & Naringin & 10.24 & - & - & 579.1736 & 27,936 \\
\hline 20 & Kaempferol-3-glucuronide & 11.84 & 465.1023 & 7577 & 463.0871 & 8259 \\
\hline 21 & $\begin{array}{l}\text { Quercetin- } \\
\text { 3-O- } \beta \text {-D-glucopyranoside }\end{array}$ & 12.26 & - & - & 463.0877 & 231,855 \\
\hline 22 & Quercetin & 12.29 & 303.0495 & 96085 & - & - \\
\hline 23 & $\begin{array}{l}\text { N-Deacetyl- } \\
\text { N-methylcolchicine }\end{array}$ & 12.61 & 372.1788 & 7489 & - & - \\
\hline 24 & Isoperlolyrine 2 & 12.9 & 265.0964 & 82453 & 263.0809 & 2075 \\
\hline 25 & Colchiceine & 13.12 & 386.1601 & 2336427 & 384.1448 & $1,907,075$ \\
\hline 26 & Anthraquinone & 13.2 & 209.0599 & 7183 & - & - \\
\hline 27 & Flavanonol & 13.2 & 241.0854 & 6229 & - & - \\
\hline 28 & $\begin{array}{l}\text { 6-Hydroxykaempferol- } \\
\text { 3-O-glucoside }\end{array}$ & 14.61 & 465.1025 & 3279 & 463.0876 & 3857 \\
\hline 29 & $\begin{array}{l}\text { 6-Methoxykaempferol- } \\
\text { 3-O- } \beta \text {-D-glucopyranoside }\end{array}$ & 14.89 & - & - & 477.1037 & 35,244 \\
\hline 30 & Isoquercetin & 16.12 & 465.1023 & 4261 & - & - \\
\hline 31 & 2,3-didemthylcolchicine & 16.66 & 372.1433 & 167107 & 370.1282 & 18,762 \\
\hline 32 & Gloriosine & 17.03 & 386.1598 & 882243 & 384.1441 & 73,037 \\
\hline 33 & 3-demethylcolchicine & 18.4 & 386.1613 & 2596448 & - & - \\
\hline 34 & Colchicine & 18.59 & 400.1744 & 2315151 & - & - \\
\hline 35 & Procyanidin A2 & 18.6 & - & - & 575.1203 & 51,849 \\
\hline 36 & n-deacetylcolchicine & 18.66 & 358.1664 & 821243 & - & - \\
\hline 37 & Morin & 19.1 & - & - & 301.0336 & 52,761 \\
\hline 38 & Luteolin & 19.33 & 287.054 & 6150 & 285.0392 & 6471 \\
\hline 39 & Cornigerine & 20.45 & 384.1434 & 438658 & - & - \\
\hline 40 & Futoenone & 24.41 & 341.1379 & 739283 & - & - \\
\hline 42 & Balanophonin & 28.24 & 357.1324 & 32373 & - & - \\
\hline
\end{tabular}

\subsection{Effect of Colchicine on Cell Viability}

Effect on cell viability was evaluated using crystal violet staining assay [45] against six human cancer cell lines (A549, HCT116, MCF-7, MDA-MB231, PANC-1, and SiHa) using doses ranging from 0-60 $\mathrm{nM}$ after $48 \mathrm{~h}$ of incubation. In vitrocytotoxic effect of colchicine was observed in a dose-dependent manner, upto $40 \mathrm{nM}$ in MDA-MB231 and $80 \mathrm{nM}$ inPANC-1, MCF-7, HCT116, SiHa, and A549. Purified colchicine showed the least cytotoxicity at low doses and at higher concentration it showed a plateau-shaped dose-response curve, suggesting that the cells became resistant to colchicine at higher concentrations (Figure 4A,B). 


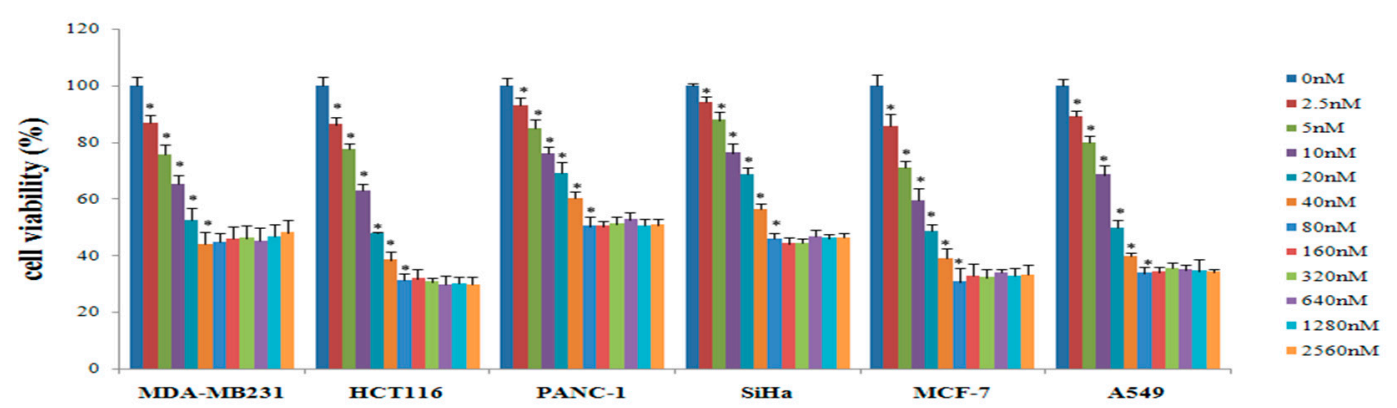

(A)

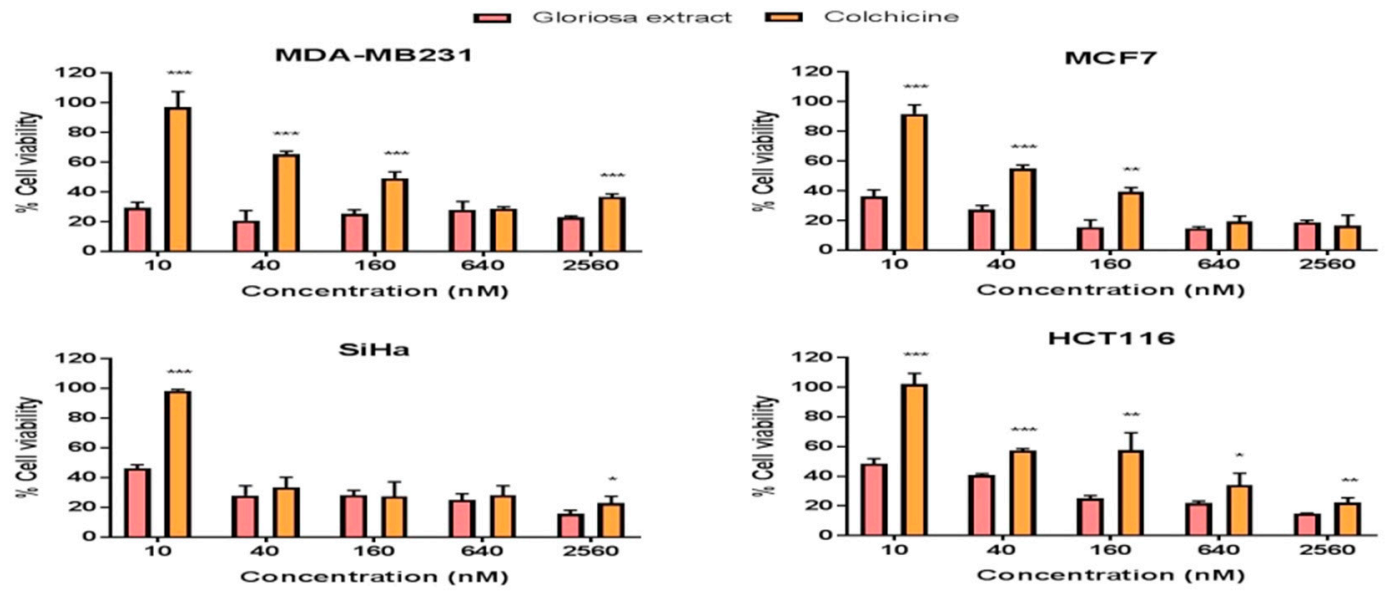

(B)

Figure 4. (A) Effect of colchicine on cell viability in six human cancer cell lines (MDA-MB231, HCT116, PANC-1, SiHa, MCF-7, and A549) based on Crystal Violet Assay. (B) The comparative effect of colchicine and Gloriosa extract (Colchicine content in Gloriosa extract) on cell viability against four human cancer cell lines (MDA-MB231, HCT116, SiHa, and MCF-7).

\subsection{Effect of Colchicine on Cell Migration}

Cell migration was studied using in vitro scratch assay in six human cancer cell lines over a period of $72 \mathrm{~h}$ (Figure 5). In the untreated cells, the scratch area was closed at $24 \mathrm{~h}$ inMDA-MB231 and $\mathrm{SiHa} ; 48 \mathrm{~h}$ in A549 andPANC-1; and $72 \mathrm{~h}$ in HCT116 and MCF-7. Cells treated with low concentration of colchicine $(2.5 \mathrm{nM})$ covered the scratch area at $24 \mathrm{~h}$ in MDA-MB231; $48 \mathrm{~h}$ in A549; SiHa and PANC-1; and $72 \mathrm{~h}$ in HCT116 and MCF-7 (Figure 5A-F).The reduced rate of cell migration was noticed with 5-20 $\mathrm{nM}$ concentration and the antiproliferative effect of colchicine was observed at 40 and $60 \mathrm{nM}$ of colchicine, even $72 \mathrm{~h}$ post-scratch, in all studied cell lines (Figure $6 \mathrm{~A}-\mathrm{F}$ ).

\subsection{Analysis of Cell Cycle}

The effect of colchicine on cell cycle progression was studied in six human cancer cell lines (Figure 7). The result demonstrated that untreatedA549 cells distributed 52\% in G0/G1 (2C DNA), and $23 \%$ in the G2/M phase (4C DNA), whereas at higher concentrations of colchicine (40 and $60 \mathrm{nM})$, the cells showed mitotic arrest ( $80 \%$ in G2/M phase). At a $20 \mathrm{nM}$ concentration, G0/G1 and G2/M peaks were almost equal. Untreated SiHa contained $69 \%$ cells in the G0/G1, and $16 \%$ in the G2/M phase (Figure 7). The mitotic arrest was initiated at $20 \mathrm{nM}$ in SiHa, contained $46 \%$ cells in G0/G1, and $32 \%$ in the G2/M phase, while at $60 \mathrm{nM}$, the cells were distributed equally in both phases. 

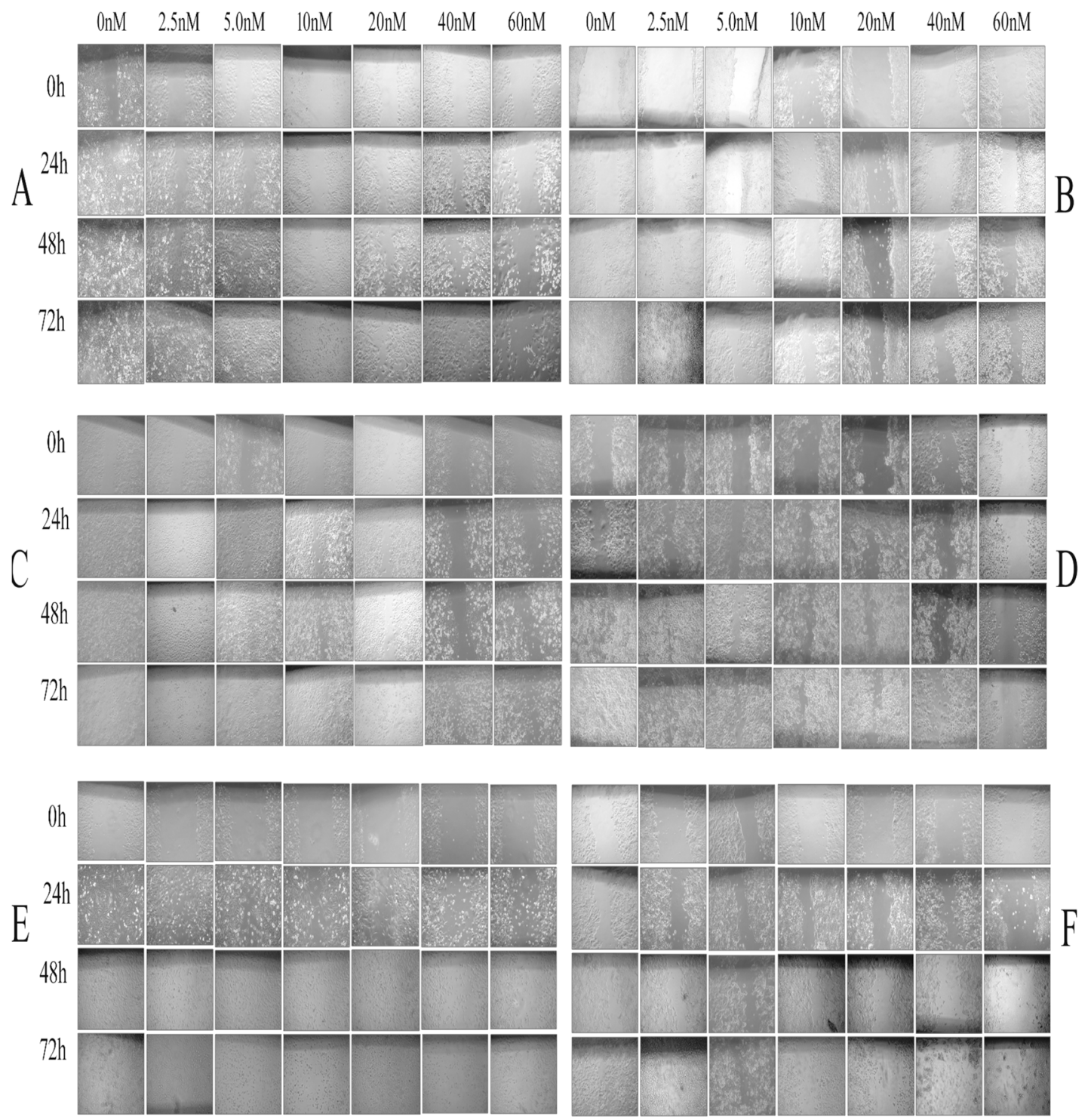

Figure 5. Phase contrast microscope images at $0,24,48$, and $72 \mathrm{~h}$ post-scratch in six human cancer cell lines treated with varying doses of colchicine (2.5-60 nM). (A) A549, (B) HCT116, (C) SiHa, (D) PANC-1, (E) MDA-MB231, and (F) MCF-7.

The untreated PANC-1 and MCF-7 cells showed a normal distribution in the cell cycle phase (PANC-1-60\% G0/G1 and 19\% G2/M, MCF-7-52\% G0/G1 and 18\% G2/M), while thetreated cells with 20-60 nM showed increasing4C (DNA Count; 4C) and decreasing 2C (DNA Count; 2C) content in both cell lines. Similarly, the untreated HCT116 cells distributed $64 \%$ in the G0/G1 and 19\% in the G2/M phase within creasing $4 \mathrm{C}$ and decreasing $2 \mathrm{C}$ content at both concentrations (40 nM and $60 \mathrm{nM}$ ). In MDA-MB231, the control showed a normal cell cycle distribution; $69 \%$ of cells in the G0/G1 and $19 \%$ in the G2/M phase (Figure 7), whereas at higher concentrations of colchicine (60 nM), the cells showed mitosis arrest (G2/M phase). Increased 4C DNA and decreased 2C DNA content was observed at $40 \mathrm{nM}$, which indicated initiation of mitotic arrest at the same concentration. 
A
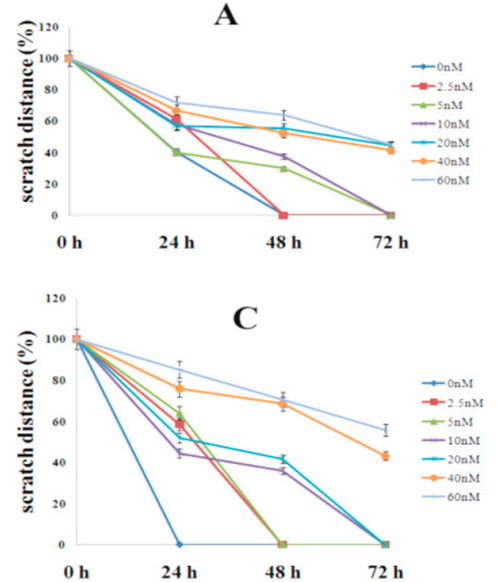

E

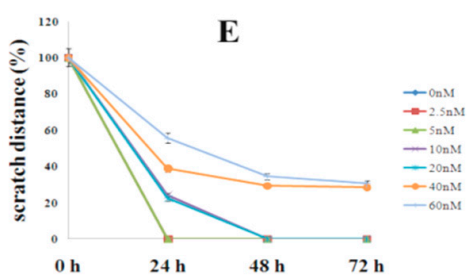

B

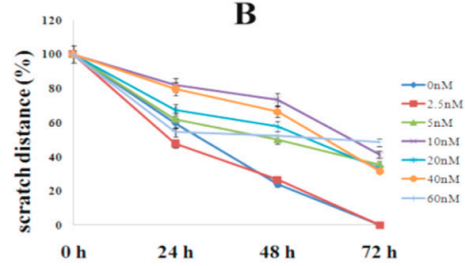

D
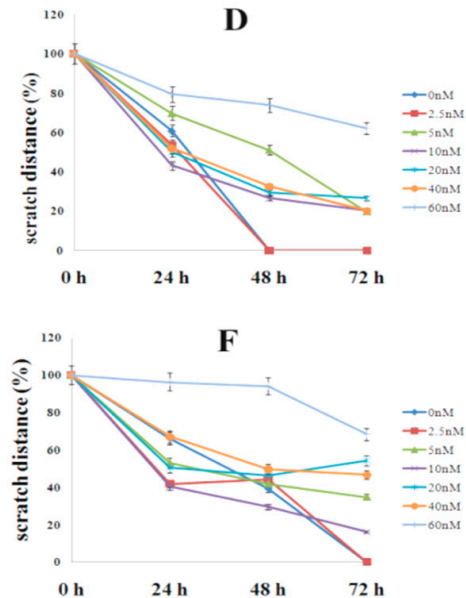

Figure 6. Antiproliferative effect of colchicine on cell migration. Cells were treated with varying doses of colchicine $(2.5-60 \mathrm{nM})$ and the distance they moved was measured using a scratch assay at different time-points $(0,24,48$, and $72 \mathrm{~h})$. Each line is labeled with the drug concentrations used in the experiment. (A) A549, (B) HCT116, (C) SiHa, (D) PANC-1, (E) MDA-MB231, and (F) MCF-7.
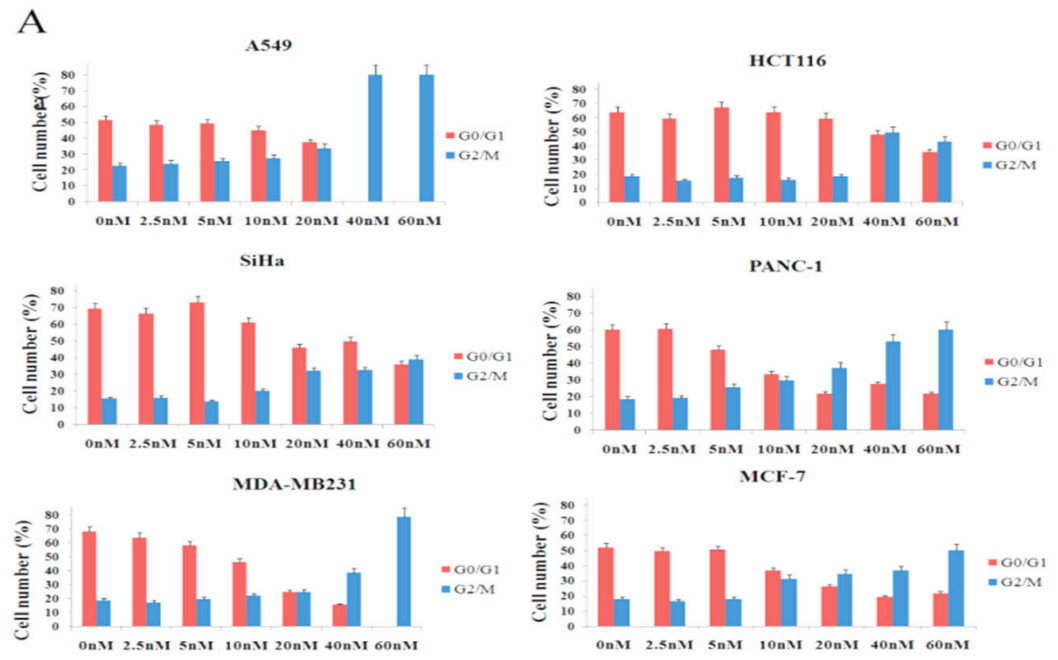

B
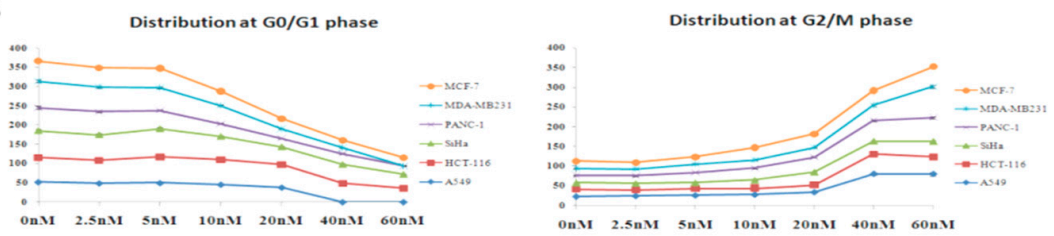

Figure 7. Effect of colchicine on cell cycle distribution in six human cancer cell lines (A549, HCT116, SiHa, PANC-1, MDA-MB231, and MCF-7). (A) Cells treated with different doses of colchicine (2.5-60 nM) for $24 \mathrm{~h}$ were stained with Propidium Iodide (PI) and analyzed using flow cytometry, based on 8000 cell counts. (B) Dose-response curve showing the effect of colchicine at the G0/G1 and G2/M phase, using doses ranging from 0 to $60 \mathrm{nM}$, using six human cancer cell lines. 


\section{Discussion}

Considering the medicinal value of colchicine, we attempted to optimize colchicine extraction from Gloriosa superba seeds. Super Critical Fluid $\left(\mathrm{CO}_{2}\right)$ extractor (SCFE) was used to obtain the crude seed extract (Figure 1). Therefore, the SCF extraction conditions $\left(60^{\circ} \mathrm{C}\right.$ per $400 \mathrm{bar}$; flow rate- $100 \mathrm{~g} / \mathrm{min}$ of liquid $\mathrm{CO}_{2}$ with $3 \mathrm{~g}$ water as co-solvent) could be admitted as the best method to extract colchicine from the seeds of Gloriosa (Table 1). The temperature and pressure had significant influence on the extraction of colchicine. The crude seed extract was subjected to column chromatography for further purification. The isolated colchicine was quantified $(99.82 \%)$ by HPLC. Colchicine extracted from Gloriosa through the solvent extraction method has already been reported $[13,14,46]$. Chemical composition screening of the Gloriosa seeds was performed using LC-MS QTof.

Colchicine possesses anticancer activity and the anticancer mechanism involves the colchicine-tubulin interaction, which disrupts microtubule dynamics [36,47-49]. It has been long used as a medicine for the treatment of gout and Familial Mediterranean Fever [29,30]. Recent studies have opened up the possibility of safe use of colchicine as an anti-cancer medicine with a controlled dose administration [47]. Colchicine causes high fatality after acute ingestions exceeding $0.5 \mathrm{mg} / \mathrm{kg}$. The effective plasma concentrations ranges from 0.5 to $3 \mathrm{ng} / \mathrm{mL}$ and the toxic effects appear at a level of $3 \mathrm{ng} / \mathrm{mL}$ or above $[49,50]$. Our results demonstrated that purified colchicine was merely toxic at low concentrations and exhibited cell cytotoxicity in a dose-dependent manner up to a concentration of $40 \mathrm{nM}$ in MDA-MB231, $80 \mathrm{nM}$ in PANC-1, HCT116, MCF-7, SiHa, and A549.Concentrations higher than this give a plateau-shaped dose-response curve, indicating that the cells perhaps develop a resistance to colchicine [41]. Colchicine has been reported to play an anticancer role in lung cancer, at doses of $50 \mathrm{nM}$, and at doses of $100 \mathrm{nM}$ in breast and liver cancer [41,47]. The significant antiproliferative effect of colchicine on cancer cell lines was observed at $40 \mathrm{nM}$ and $60 \mathrm{nM}$ concentrations $72 \mathrm{~h}$ post-scratch and at low concentrations ( $2.5 \mathrm{nM}$ and $5 \mathrm{nM}$ ), it did not have any effect on antiproliferation (Figure 4).

Colchicine inhibits the progression from the $\mathrm{G} 1$ to the $\mathrm{M}$ phase (G2/M phase arrest) by disrupting the formation of the mitotic spindle required for mitosis [32]. It was reported that colchicine causedG2/M phase arrest at $50 \mathrm{nM}$ concentrations in A549 [47]. In the present study, our result showed that colchicine caused mitotic arrest (G2/M phase) at 40 and $60 \mathrm{nM}$ concentrations, in $\mathrm{A} 549$ and at $60 \mathrm{nM}$ in MDA-MB231. The other three cell lines (SiHa, HCT116, and PANC-1) did not cause complete mitotic arrest at $60 \mathrm{nM}$, however, high G2/M (4C DNA) and low G0/G1peak (2C DNA) was observed, which indicated that mitotic arrest was initiated (Figure 5A,B). The observed cell-line-specific differences in the cell cycle progression from the G1 to the M phase with colchicine treatment might be due to the differences in drug uptake or other cell-type-specific drug effects. These findings indicated that colchicine was least toxic at low concentrations (concentrations included in the clinically acceptable range), but did not show any antiproliferative effect and caused no mitotic arrest. The uncontrolled rate of mitosis is aprominent feature of cancer cells, which makes them more vulnerable to mitotic poison than the noncancerous cells. The available reports suggest the use of colchicine at a dose of $2.5 \mathrm{nM}$ is considered safe in lung cancer [47].

\section{Conclusions}

In conclusion, to avoid side effects of impurities present in colchicine, we developed methods of extraction and purification that produced a refined colchicine with high levels of activity, demonstrating its possible medicinal use. The present findings support that purified colchicine can be used in lung cancer, breast cancer, colon cancer, pancreatic cancer, and cervical cancer, because it was merely toxic at low concentrations and caused no mitotic arrest. Further pharmacological and clinical studies are required to establish these findings.

Author Contributions: A.B. and C.S.J. designed the experiment and analyzed the data; C.S.J., S.K.D., A.J., L., S.V., V.S., and S.P. performed the experiments; C.S.J., V.S., and A.J. wrote; C.S.J. reviewed the paper; N.S. and V.K.S. only commented on the manuscript. All authors have read and approved the manuscript. 
Funding: There was no financial support availed for conducting this study.

Acknowledgments: The authors are delighted to convey their regards to Param Pujya Swami Ramdev Ji for his moral and institutional supports to perform this research. We are thankful to Sushil Joshi, D. Rajagopal, and Sunil Shukla for their scientific support. We are also thankful to Lalit Mohan, Tarun Ji, and Gagan Ji for their administrative support.

Conflicts of Interest: The authors declare no competing financial interest.

\section{References}

1. Ambasta, S.P. The Useful Plants of India; National Institute of Science Communication: New Delhi, India, 1986; p. 238.

2. Nadkarni, K.M. Indian Materia Medica, Vol. I.-II; Popular Prakashan Private Limited: Mnmbai, India, 1976; pp. 1-968.

3. Pulliah, T. Medicinal plants in India, vol. I; Regency Publications: New Delhi, India, 2002; pp. 269-270.

4. Capraro, H.G.; Brossi, A. Tropolonic colchicum alkaloids. The Alkaloids: Chemistry and Pharmacology; Academic Press: New York, NY, USA, 1984; pp. 1-70.

5. Kuo, M.C.; Chang, S.J.; Hsieh, M.C. Colchicine Significantly Reduces Incident Cancer in Gout Male Patients A 12-Year Cohort Study. Medicine 2015, 94, 1-6. [CrossRef] [PubMed]

6. Finnie, J.F.; Van Staden, J. Gloriosa superba L. (Flame Lily): Micropropagation and In Vitro Production of colchicines. Biotechnology in Agriculture and Forestry, Medicinal and Aromatic Plants VI; Springer: Berlin/Heidelberg, Germany, 1994; Volume 26, pp. 146-166.

7. Chopra, R.N.; Nayar, S.L.; Chopra, I.C. Glossary of Indian Medicinal Plants; PID, CSIR: New Delhi, India, 1956; p. 125.

8. Sarin, Y.K.; Jamwal, P.S.; Gupta, B.K.; Atal, C.K. Colchicine from seeds of Gloriosa superba. Curr. Sci. 1977, $43,87$.

9. Srivastava, U.C.; Chandra, V. Gloriosa superba Linn. (Kalihari) an important colchicine producing plant. J. Res. Ind. Med. 1977, 10, 92-95.

10. Bellet, P.; Gaignault, J.C. Gloriosa superba L. production de substances colchiciniques. Ann. Pharm. Fr. 1985, 43, 345-347. [PubMed]

11. Husek, A.; Sutlupinar, N.; Potesilova, A.; Dvorackova, S.; Hanus, V.; Sedmera, P.; Malon, P.; Simanek, V. Alkaloids and phenolics of three Merendera Species. Phytochemistry 1989, 28, 3217-3219. [CrossRef]

12. Husek, A.; Sutlupinar, N.; Sedmera, P.; Volgelein, F.; Valka, I.; Simanek, V. Alkaloids and phenolics of Colchicum turcicum. Phytochemistry 1990, 29, 3058-3060. [CrossRef]

13. Joshi, C.S.; Priya, E.S.; Mathela, C.S. Isolation and anti-inflammatory activity of colchicinoids from Gloriosa superba seeds. Pharm. Biol. 2010, 48, 206-209. [CrossRef]

14. Ellington, E.; Bastida, J.; Viladomat, F.; Codina, C. Super Critical carbon dioxide extraction of colchicine and related alkaloids from seeds of Colchicum autumnale. Phytochem. Anal. 2003, 4, 164-169. [CrossRef]

15. Mansoori, G.A.; Schulz, K.; Martinelli, E. Bioseparation using Super Critical Fluid Extraction/Retrograde Condensation. Bio. Technol. 1988, 6, 393-396.

16. Martinelli, E.; Schulz, K.; Mansoori, G.A. Super Critical Fluid Extraction/Retrograde Condensation with Application in Biotechnology; CRC Press: Boca Raton, FL, USA, 1991; pp. 451-478.

17. Lang, Q.Y.; Wai, C.M. Super Critical Fluid Extraction in Herbal and Natural Product Studies-A Practical review. Talanta 2001, 53, 771-782. [CrossRef]

18. Mohamed, R.S.; Masoori, G.A. The use of Super Critical Fluid Extraction Technology in Food Processing. Food Technol. Mag. 2002, 20, 134-139.

19. Ndiomu, D.P.; Simpson, C.F. Some Applications of Super Critical Fluid Extraction. Anal. Chim. Acta 1998, 213, 237-243. [CrossRef]

20. King, M.B.; Bott, T.R. Extraction of Natural Products Using Near-Critical Solvents; Chapman and Hall: London, UK, 1993; pp. 1-49.

21. Moore, W.N.; Taylor, L.T. Gaining greater selectivity in the Super Critical Fluid Extraction of digoxin from Digitalis lanata leaves. Phytochem. Anal. 1997, 8, 238-243. [CrossRef]

22. Chester, T.L.; Pinkston, J.D.; Raynie, D.E. Super Critical Fluid chromatography and extraction. Anal. Chem. 1996, 68, 487-514. [CrossRef] 
23. Chester, T.L.; Pinkston, J.D.; Raynie, D.E. Super Critical Fluid Chromatography and Extraction. Anal. Chem. 1998, 70, 301-320. [CrossRef]

24. Sihvonen, M.; Jarvenpaa, E.; Heitaniemi, V.; Huopalthi, R. Advances in Super Critical carbon dioxide Technologies. Trends Food Sci. Technol. 1999, 10, 217-222. [CrossRef]

25. Mukhopadhyay, M. Natural Extracts Using Super Critical Carbon Dioxide; CRC Press: Boca Raton, FL, USA, 2000.

26. Ravelli, R.B.G.; Gigant, B.; Curmi, P.A.; Jourdain, I.; Lachkar, S.; Sobel, A.; Knossow, M. Insight into tubulin regulation from a complex with colchicine and a stathmin-like domain. Nature 2004, 428, 198-202. [CrossRef]

27. Richette, P.; Bardin, T. Colchicine for the treatment of gout. Expert Opin. Pharmacother. 2010, 11, $2933-2938$. [CrossRef] [PubMed]

28. Samy, R.P.; Twin, M.M.; Gopalkrishnakone, P.; Ignacimuthu, S. Ethanobotanical survey of folk plants for treatment of snake bites in southern part of Tamilnadu, India. J. Ethnopharmacol. 2008, 115, 302-312. [CrossRef] [PubMed]

29. Cerquaglia, C.; Diaco, M.; Nucera, G.; La Regina, M.; Montalto, M.; Manna, R. Pharmacological and clinical basis of treatment of Familial Mediterranean Fever (FMF) with colchicine or analogues: An update. Curr. Drug Targets Inflamm. Allergy 2005, 4, 117-124. [CrossRef]

30. Kallinich, T.; Haffner, D.; Niehues, T.; Huss, K.; Lainka, E.; Neudorf, U.; Schaefer, C.; Stojanov, S.; Timmann, C.; Keitzer, R.; et al. Colchicine use in children and adolescents with Familial Mediterranean Fever: Literature review and consensus statement. Pediatrics 2007, 119, 474-483. [CrossRef] [PubMed]

31. Jordan, M.A.; Wilson, L. Microtubules and actin filaments: Dynamic targets for cancer chemotherapy. Curr. Opin. Cell Biol. 1998, 10, 123-130. [CrossRef]

32. Jordan, M.A.; Wilson, L. Microtubules as a target for anticancer drugs. Nat. Rev. Cancer 2004, 4, $253-265$. [CrossRef] [PubMed]

33. Downing, K.H. Structural basis for the interaction of tubulin with proteins and drugs that affect microtubule dynamics. Ann. Rev. Cell Dev. Biol. 2000, 16, 89-111. [CrossRef] [PubMed]

34. Rowinsky, E.K.; Donehower, R.C. The clinical pharmacology and use of antimicrotubule agents in cancer chemotherapeutics. Pharmacol. Ther. 1991, 52, 35-84. [CrossRef]

35. Taylor, E.W. The mechanism of colchicine inhibition of mitosis. I. Kinetics of inhibition and the binding of H3-Colchicine. J. Cell. Biol. 1965, 25, 145-160. [CrossRef]

36. Yan, L.; Chen, J.; Xiao, M.; Li, W.; Miller, D.D. An Overview of Tubulin Inhibitors That Interact with the Colchicine Binding Site. Pharm. Res. 2012, 29, 2943-2971.

37. Eigsti, O.J.P.; Dustin, J.R. Colchicine; Iowa State College Press: Ames, Iowa, 1955.

38. Brancale, A.; Silvestri, R. Indole, a core nucleus for potent inhibitors of tubulin polymerization. Med. Res. Rev. 2007, 27, 209-238. [CrossRef]

39. Otto, A.M.; Paddenberg, R.; Schubert, S.; Mannherz, H.G. Cell-cycle arrest, micronucleus formation, and cell death in growth inhibition of MCF-7 breast cancer cells by tamoxifen and cisplatin. J. Cancer Res. Clin. Oncol. 1996, 122, 603-612. [CrossRef]

40. Wang, S.T.; Ho, H.J.; Lin, J.T.; Shiehand, J.J.; Wu, C.Y. Simvastatin-induced cell cycle arrest through inhibition of STAT3/SKP2 axis and activation of AMPK to promote p27 and p21 accumulation in hepatocellular carcinoma cells. Cell Death Dis. 2017, 8, 1-12. [CrossRef]

41. Lin, Z.Y.; Wu, C.C.; Chuang, Y.H.; Chuang, W.L. Anti-cancer mechanisms of clinically acceptable colchicine concentrations on hepatocellular carcinoma. Life Sci. 2013, 93, 323-328. [CrossRef]

42. Cocco, G.; Chu, D.C.; Pandolfi, S. Colchicine in clinical medicine. A guide for internists. Eur. J. Intern. Med. 2010, 21, 503-508. [CrossRef] [PubMed]

43. Karar, M.G.E.; Kuhnert, N. UPLC-ESI-Q-TOF-MS/MS Characterization of phenolics from Crataegusmonogyna and Crataegus laevigata (Hawthorn) leaves, fruits and their herbal derived drops (CrataeguttTropfen). J. Chem. Biol. Ther. 2015, 1, 102. [CrossRef]

44. Luo, J.L.; Lu, F.L.; Liu, Y.C.; Shih, Y.C.; Lo, C.F. Fingerprint analysis of Ginkgo biloba extract and Ginkgo semen in preparations by LC-Q-TOF/MS. J. Food Drug Anal. 2013, 21, 27-39.

45. Sliwka, L.; Wiktorska, K.; Suchocki, P.; Milczarek, M.; Mielczarek, S.; Lubelska, K.; Cierpial, T.; Łyżwa, P.; Kiełbasiński, P.; Jaromin, A.; et al. The Comparison of MTT and CVS Assays for the Assessment of Anticancer Agent Interactions. PLoS ONE 2016, 11, e0155772. [CrossRef] [PubMed] 
46. Kannan, S.; Wesley, S.D.; Ruba, A.; Rajlashmi, A.R.; Kumaragurubaran, K. Optimization of solvent for effective isolation of colchicines from Gloriosa superba. Nat. Prod. Res. 2007, 21, 469-472. [CrossRef] [PubMed]

47. Bhattacharya, S.; Das, A.; Datta, S.; Ganguli, A.; Chakrabarti, G. Colchicine induces autophagy and senescence in lung cancer cells at clinically admissible concentration: Potential use of colchicine in combination with autophagy inhibitor in cancer therapy. Tumour Biol. 2016, 8, 10653-10664. [CrossRef] [PubMed]

48. Stanton, R.A.; Gernert, K.M.; Nettles, J.H.; Aneja, R. Drugs that target dynamic microtubules: A new molecular perspective. Med. Res. Rev. 2011, 31, 443-481. [CrossRef]

49. Ferron, G.M.; Rochdi, M.; Jusko, W.J.; Scherrmann, J.M. Oral absorption characteristics and pharmacokinetics of colchicine in healthy volunteers after single and multiple doses. J. Clin. Pharmacol. 1996, 36, 874-883. [CrossRef]

50. Sivakumar, G. Colchicine semisynthetics: Chemotherapeutics for cancer. Curr. Med. Chem. 2013, 20, 892-898.

Sample Availability: Samples of the compounds are not available from the authors.

(C) 2019 by the authors. Licensee MDPI, Basel, Switzerland. This article is an open access article distributed under the terms and conditions of the Creative Commons Attribution (CC BY) license (http://creativecommons.org/licenses/by/4.0/). 